\title{
Budowa i znaczenie II systemu sekrecji białek w ekologii i patogenezie Legionella pneumophila
}

\author{
Agata Małek¹, Bożena Kowalczyk², Marta Palusińska-Szysz ${ }^{\star 2}$ \\ ${ }^{1}$ Katedra i Zakład Chemii Medycznej, Wydział Lekarsko-Dentystyczny, Uniwersytet Medyczny w Lublinie \\ ${ }^{2}$ Katedra Genetyki i Mikrobiologii, Instytut Nauk Biologicznych, Wydział Biologii i Biotechnologii, Uniwersytet Marii Curie-Skłodowskiej w Lublinie
}

Abstract

Pałeczki Legionella pneumophila pasożytują w komórkach odległych filogenetycznie gospodarzy, w środowisku wodnym w pierwotniakach, a w organizmie człowieka w makrofagach alweolarnych. Zdolność tych bakterii do wewnątrzkomórkowego namnażania się w komórkach fagocytujących, wyspecjalizowanych do niszczenia mikroorganizmów, ma podstawowe znaczenie dla rozwoju nietypowego zapalenia płuc zwanego chorobą legionistów. Umiejscowione na kilku różnych loci chromosomu bakteryjnego geny II systemu sekrecji $L$. pneumophila kodują co najmniej 25 białek, w tym enzymy o aktywności lipolitycznej, proteolitycznej, rybonukleazy oraz białka unikalne bakterii Legionella. W środowisku naturalnym T2SS $L$. pneumophila odgrywa decydującą rolę w ekologii tych drobnoustrojów determinując ich zdolność do przeżycia zarówno w postaci planktonicznej, jak i w strukturach biofilmu w słodkowodnych zbiornikach o niskiej temperaturze. Białka T2SS umożliwiają L. pneumophila zakażenie różnych gatunków pierwotniaków, a substraty tego systemu określają zakres pierwotniaczego gospodarza. Namnażanie się bakterii w różnorodnych pierwotniakach przyczynia się do ich rozsiewania oraz transmisji do antropogenicznych źródeł. Białka wydzielane za pomocą II systemu sekrecji determinują również zdolność $L$. pneumophila do zakażania mysich makrofagów alweolarnych i szpiku kostnego, ludzkich makrofagów linii U937 i THP-1 oraz komórek nabłonkowych pęcherzyków płucnych. Enzymy wydzielane za pomocą tego systemu, takie jak: proteazy, aminopeptydazy czy fosfolipazy umożliwiają pozyskanie substancji pokarmowych oraz powodują destrukcję tkanki płucnej myszy. W organizmie człowieka białka T2SS przyczyniają się do osłabienia wrodzonej odpowiedzi immunologicznej na zakażenie $L$. pneumophila przez hamowanie indukcji prozapalnych cytokin (IL-6, TNF- $\alpha$, IL-1 oraz IL-8).

Keywords

Legionella pneumophila • choroba legionistów • II system sekrecji • czynniki wirulencji

Otrzymano: 30.11.2020, Zaakceptowano: 15.07.2021

\section{Abstract}

Legionella pneumophila bacilli parasitize in the cells of phylogenetically distant hosts: protozoa in the aquatic environment and alveolar macrophages in the human body. The ability of these bacteria to multiply intracellularly in phagocytic cells specialized to destroy microorganisms is critical to the development of atypical pneumonia known as Legionnaires' disease. Located at several different loci of the bacterial chromosome, the genes of the type II secretion system of $L$. pneumophila encode at least 25 proteins, including enzymes with lipolytic, proteolytic, and ribonuclease activity and proteins that are unique for Legionella. In the natural environment, the T2SS system of $L$. pneumophila plays a decisive role in the ecology of these microorganisms, determining their ability to survive in freshwater reservoirs at low temperatures, both in planktonic form and in biofilm structures. T2SS proteins enable L. pneumophila to infect various species of protozoa, and the substrates of this system determine the extent of the protozoan host. The multiplication of bacteria in a wide range of protozoa contributes to their dissemination and transmission to anthropogenic sources. Proteins secreted by the type II secretion system also determine the ability of $L$. pneumophila to infect murine alveolar macrophages and bone marrow, human macrophages of the U937 and THP-1 lines, and alveolar epithelial cells. Enzymes secreted by this system, such as proteases, aminopeptidases or phospholipases, contribute to the destruction of lung tissue, in the mouse model of pneumonia. In the human body, T2SS proteins contribute to the reduction of the innate immune response to L. pneumophila infection by inhibiting the induction of pro-inflammatory cytokines (IL-6, TNF- $\alpha$, IL-1, and IL-8).

Keywords

Legionella pneumophila • Legionnaires' disease • type II system of protein secretion • virulence factors

Received: 30.11.2020, Accepted: 15.07.2021

*Corresponding author e-mail: marta.szysz@poczta.umcs.lublin.pl

(a) BY-Nc-ND (2021Marta Palusińska-Szysz et al. This work is licensed under the Creative Commons Attribution-NonCommercial-NoDerivs 4.0 License. 


\section{Wprowadzenie}

Od czasu identyfikacji bakterii jako czynników etiologicznych chorób dążono do poznania sposobu, w jaki mikroorganizmy manipulują sygnalizacją komórkową gospodarza, aby móc namnażać się wewnątrz jego organizmu. W czasie koewolucji z żywicielami wiele bakterii chorobotwórczych wykształciło wysoce wyspecjalizowane systemy translokacji białek [1]. Te wielobiałkowe maszynerie mogą „wstrzykiwać” tzw. białka efektorowe bezpośrednio do komórek gospodarza, zaburzając przebieg różnorodnych procesów komórkowych na korzyść bakterii [2]. Ważną grupą białek ulegających sekrecji są bakteryjne czynniki wirulencji. Aktywność oraz wydajność bakteryjnych systemów wydzielania w znacznym stopniu determinuje zjadliwość chorobotwórczych mikroorganizmów [3].

Funkcjonowanie u bakterii systemu sekrecji typu II stanowi jedną ze strategii, za pomocą których Gram-ujemne patogeny wydzielają białka do środowiska zewnątrzkomórkowego i/ lub docelowych komórek gospodarza [4]. System ten jest charakterystyczny przede wszystkim dla bakterii należących do $\alpha$-, $\beta$-, $\gamma$ - oraz $\delta$-Proteobacteria [5, 6]. Do mikroorganizmów, dla których system ten odgrywa istotną rolę w wirulencji, zaliczyć można takie oportunistyczne patogeny jak: Legionella pneumophila, Pseudomonas aeruginosa, Vibrio cholerae, Escherichia coli, Klebsiella pneumoniae, Acinetobacter baumanii czy Yersinia enterocolitica. Wśród drobnoustrojów zawierających II system sekrecji znajdują się również patogeny roślinne: Dickeya dadantii, Erwinia amylovora, Pectobacterium carotovorum, Ralstonia solanacearum, Xanthomonas campestris, Xanthomonas oryzae oraz Xylella fastidiosa. Ponadto T2SS występuje także u bakterii niepatogennych, pełniąc funkcję pomocniczą w procesach symbiozy z organizmem eukariotycznym [7, 8].

Wydajność T2SS jest w znacznym stopniu zróżnicowana w zależności od gatunku bakterii oraz warunków środowiska. Za jego pośrednictwem mikroorganizm może wydzielać zarówno zaledwie jedno, jak i kilkadziesiąt białek, obejmujących zróżnicowany zestaw toksyn oraz enzymów o potencjale degradacyjnym, a także innych efektorów, w tym całkiem nowych, nieopisanych jak dotąd białek. Możliwości T2SS w pełni ilustrują te bakterie, które wykorzystują go zarówno do przetrwania w środowisku, jak i w procesach związanych z ich zjadliwością [7]. Przykładem takiego mikroorganizmu jest $L$. pneumophila.

\section{L. pneumophila - występowanie i chorobotwórczość}

L. pneumophila jest mikroorganizmem szeroko rozpowszechnionym w przyrodzie, występującym zarówno w naturalnych jak i sztucznych zbiornikach wodnych [9]. W środowisku wodnym L. pneumophila namnaża się wewnątrz komórek pierwotniaków, głównie gatunków należących do rodzajów Acanthamoeba, Vermamoeba oraz Naegleria [10]. W organizmie człowieka bakterie Legionella wykazuja zdolność do proliferacji w makrofagach alweolarnych, komórkach nabłonkowych pęcherzyków płucnych typu I i II, a także w monocytach lub fibroblastach [11].

Zakres wywoływanych przez bakterie z rodzaju Legionella objawów klinicznych jest szeroki i obejmuje zarówno ciężkie, potencjalnie śmiertelne zapalenie płuc (choroba legionistów), jak i łagodne, samoistnie ustępujące stany grypopodobne (gorączka Pontiac) oraz zakażenia pozapłucne. Okres inkubacji choroby legionistów wynosi 2-14 dni. Do objawów choroby należą: gorączka powyżej $38,8^{\circ} \mathrm{C}$, kaszel, dreszcze, bóle mięśni lub stawów, duszność, ból w klatce piersiowej, nudności lub wymioty, a także zaburzenia neurologiczne. Bakterie należące do rodzaju Legionella mogą rozprzestrzeniać się za pośrednictwem układu krwionośnego oraz limfatycznego do innych narządów: serca, wątroby, nerek, śledziony, szpiku kostnego, węzłów chłonnych oraz ośrodkowego układu nerwowego [12].

Spośród obecnie znanych 65 gatunków należących do rodzaju Legionella wszystkie są potencjalnie patogenne dla ludzi, ale przyczyną większości potwierdzonych przypadków choroby legionistów jest L. pneumophila. Szacuje się, że około 80-90\% zakażeń tymi bakteriami wywoływanych jest przez L. pneumophila serogrupa 1, a za 15-20\% przypadków zachorowań odpowiedzialne są pozostałe serogrupy tego patogenu lub inne gatunki Legionella [13, 14]. Mimo że stwierdzono przypadek transmisji choroby legionistów z człowieka na człowieka, do zakażenia bakteriami Legionella dochodzi głównie w wyniku wdychania skażonego aerozolu wodno-powietrznego lub na skutek aspiracji do dróg oddechowych wody zanieczyszczonej bakteriami [15, 16]. Na terenie Unii Europejskiej w 2019 r. zarejestrowano 10988 przypadków choroby legionistów, z czego 74 zachorowania wystąpiły w Polsce [17]. Liczba przypadków zachorowań jest niedoszacowana ze względu na trudności w diagnostyce pałeczek Legionella oraz nieswoiste objawy kliniczne choroby legionistów, na podstawie których trudno odróżnić legionellozowe zapalenie płuc od pneumonii o innej etiologii [18].

W cyklu życiowym L. pneumophila można wyróżnić dwie odmienne pod względem morfologii, metabolizmu i fizjologii komórki fazy: replikacyjną i transmisyjną. W fazie 
replikacyjnej bakterie, które przyjmują kształt wydłużonych pałeczek o pofałdowanej ścianie komórkowej, intensywnie namnażają się w wyspecjalizowanych wakuolach LCV, utworzonych wewnątrz komórki gospodarza [19]. Pojedyncza błona otaczająca wakuolę replikacyjną nabywa charakterystycznych cech w wyniku rekrutacji pęcherzyków gospodarza bogatych w lipidy i białka, które odróżniają tę błonę od przedziału komórkowego. $W$ tej fazie bakterie nie są cytotoksyczne, a wzór ekspresji genów wirulencji odzwierciedla zużycie składników odżywczych. Wyczerpanie się puli substancji pokarmowych jest sygnałem dla bakterii do przejścia w fazę transmisyjną, w której bakterie przybierają kształt krótkich, tępo zakończonych pałeczek o gładkiej i grubej ścianie komórkowej z wyraźnymi inkluzjami kwasu $\beta$-hydroksymasłowego [19]. Fenotypowo odrębne bakterie w fazie transmisyjnej koordynują aktywację ekspresji tzw. cech transmisyjnych (cytotoksyczności, dużej infekcyjności i zwiększonej odporności osmotycznej), które są wymagane do unikania lizosomów, ucieczki z zużytej komórki gospodarza, przetrwania w środowisku zewnątrzkomórkowym i inwazji nowego, odpowiedniego gospodarza. Występowanie dwóch naprzemiennie pojawiających się faz rozwojowych jest możliwe dzięki skoordynowanemu w czasie i przestrzeni działaniu białek wydzielanych za pomocą bakteryjnych systemów sekrecji [19]. Bakterie Legionella pneumophila mają sześć systemów sekrecji. System I sekrecji bierze udział we wczesnych etapach zakażenia komórek eukariotycznych, natomiast nie jest zaangażowany w proces wewnątrzkomórkowego namnażania się bakterii $[20,21]$. Systemy wydzielnicze typu III oraz VI umożliwiają wprowadzenie białek efektorowych bezpośrednio do cytoplazmy komórek gospodarza [21, 22]. System sekrecji typu IV L. pneumophila wydziela ponad 300 białek efektorowych niezbędnych do utworzenia niszy replikacyjnej, unikania fuzji fagosomów z lizosomami i ucieczkę z wyeksploatowanej komórki gospodarza [2]. System sekrecji typu II L. pneumophila wykorzystuje do zakażenia ameb i przetrwania w strukturach biofilmu [23]. Zdolność do tworzenia biofilmu odgrywa istotną rolę $\mathrm{w}$ procesie kolonizacji, przeżyciu, rozsiewaniu oraz patogenezie L. pneumophila. Biofilm zapewnia schronienie i składniki odżywcze, wykazuje odporność na związki bakteriobójcze oraz chlorowanie. Mutanty $L$. pneumophila defektywne w syntezie białek TatB i TatC wydzielananych za pomocą II systemu sekrecji były niezdolne do przyłączenia się do powierzchni polipropylenowych i polistyrenowych [24]. Bakterie L. pneumophila występujące $\mathrm{w}$ biofilmie tworzą niejednorodne fenotypowo subpopulacje komórek rosnących i nierosnących. Wzajemny stosunek tych bakterii jest regulowany za pomocą systemu Legionella quorum sensing (Lqs), czynnika transkrypcyjnego LvbR oraz temperatury. Nierosnące komórki $L$. pneumophila w biofilmie są metabolicznie aktywne, wykazują ekspresję genów wirulencji oraz są odporne na antybiotyki [25]. System sekrecji typu II $L$. pneumophila wykorzystuje również do wzrostu w makrofagach człowieka oraz niszczenia tkanki płucnej, a także tłumienia odpowiedzi odpornościowej człowieka na zakażenie [7].

\section{Budowa II systemu sekrecji}

System wydzielniczy typu II to wielobiałkowy aparat, który przenosi wiele czynników wirulencji, enzymów oraz innych efektorów przez błonę zewnętrzną Gram-ujemnych bakterii $[6,26,27]$. W skład bakteryjnychT2SS wchodzi 11-15 różnych białek, z których większość występuje w konserwatywnym aparacie wydzielniczym w wielu kopiach [28].

Aparat T2SS $L$. pneumophila składa się z 12 białek: T2S $\mathrm{C},-\mathrm{D},-\mathrm{E},-\mathrm{F},-\mathrm{G},-\mathrm{H},-\mathrm{I},-\mathrm{J},-\mathrm{K},-\mathrm{L},-\mathrm{M}$ oraz $\mathrm{O}$, które tworza cztery kompleksy [29, 30].

Pierwszy kompleks zbudowany jest z multimerycznego białka T2S D, które tworzy swoistą „bramę” do przejścia efektora przez błonę zewnętrzną (tzw. sekretyna - białka OM, które oligomeryzują, tworząc pory wydzielnicze) [4, 31]. Sekretyna złożona jest z czterech N-końcowych domen peryplazmatycznych (N0, N1, N2 i N3), rdzenia oraz C-końcowej domeny $S$ [32]. Zakotwiczony w błonie wewnętrznej (IM) kompleks składający się z białek T2S F, -L oraz -M tworzy obejmujący peryplazmę kanał, powstały na skutek oddziaływania $z$ sekretyną. Kompleks związany z błona zewnętrzną oraz kompleks związany $z$ wewnętrzną membraną komórkową połączone są przez tzw. „białko klamry" T2S C. Jest ono składnikiem łączącym elementy aparatu obejmujące błonę wewnętrzną z elementami błony zewnętrznej. Trzeci kompleks to struktura podobna do pilusa, składająca się z głównej pseudopiliny T2S G oraz mniejszych pseudopilin: T2S H, -I, -J oraz -K [33]. Pseudopilus obejmuje peryplazmę $w$ kanale utworzonym przez interakcję elementów kompleksu błony wewnętrznej z sekretyną. Pilusopodobny element T2SS przeprowadza określony substrat przez granicę błony zewnętrznej, działając na zasadzie mechanizmu „tłokowego" lub „śrubowego”. Oddziaływanie białka T2S G z białkiem T2S L sprzyja biogenezie pseudopilusa [7, 34, 35, 36]. Czwarty kompleks to heksametryczne białko T2S E, które jest cytoplazmatyczną ATP-azą. Białko to po rekrutacji do membrany wewnętrznej wspomaga proces wydzielania. Platforma utworzona z biakek T2S C, T2S F, T2S L oraz T2S $M$ wiąże się z cytoplazmatyczną ATPazą [6, 33]. Natomiast białko T2S $\mathrm{O}$ jest peptydazą błony wewnętrznej, która odpowiada za rozszczepienie prepiliny przed jej integracją $z$ aparatem T2SS $[4,30]$.

Obecne w T2SS niektórych Gram-ujemnych bakterii białko T2S N nie występuje w aparacie sekrecyjnym $L$. pneumophila. Element ten współtworzy część kompleksu związanego z błoną wewnętrzną. Niektóre bakterie zawierające T2SS 
kodują dwa białka oddziałujące z peptydoglikanem, które są związane z błoną wewnętrzną: T2S A oraz T2S B. Funkcją tych składników jest umiejscowienie białka T2S D w błonie zewnętrznej [32].

U niektórych Gram-ujemnych bakterii białko -PulS (OutS), zwane również „pilotyną”, jest niezbędne do prawidłowego przebiegu transportu oraz kierowania sekretyny T2S D do błony zewnętrznej [37]. N-koniec występującej w pilotynie konserwatywnej cysteiny ulega lipidacji, dzięki czemu pełni ona rolę „kotwicy” w wewnętrznej warstwie błony zewnętrznej [32]. Pilotyna nie jest jednak kodowana w genomie $L$. pneumophila, co może sugerować, że sekretyna T2S $\mathrm{D} u$ tych bakterii jest zdolna do kierowania się na błonę zewnętrzną, podobnie jak w przypadku sekretyn T2SS bakterii z rodzajów Pseudomonas oraz Xanthomonas [38]. Za ułatwienie ulokowania sekretyny w błonie komórkowej $L$. pneumophila odpowiada N-końcowa domena SPOR wiążąca peptydoglikan, podobnie jak w przypadku sekretyny PilQ $P$. aeruginosa [39, 40].

\section{Proces eksportu białek za pomocą II systemu sekrecji}

Wydzielanie białek za pomocą II systemu jest procesem dwuetapowym, w którym białka przeznaczone do sekrecji najpierw są przemieszczane przez wewnętrzną membranę bakteryjną do peryplazmy poprzez szlak Sec lub szlak Tat. W drugim etapie białka są rozpoznawane przez aparat T2SS i opuszczają komórkę przez specjalne pory utworzone w błonie zewnętrznej (ryc.1) [41]. U bakterii dominującą drogą eksportu białek z cytozolu jest szlak wydzielania ogólnego (Sec) (niesfałdowane substraty białkowe), jednak w niektórych przypadkach sfałdowane substraty pokonują barierę błony wewnętrznej na drodze szlaku podwójnej translokacji argininy (szlak Tat) [4]. Kierowanie białek do jednego z alternatywnych systemów eksportu wymaga fuzji peptydu sygnałowego specyficznego dla danego szlaku z końcem aminowym białka docelowego [42].

Substraty Sec są przeważnie syntetyzowane jako białka prekursorowe o wysokiej masie cząsteczkowej, zawierające

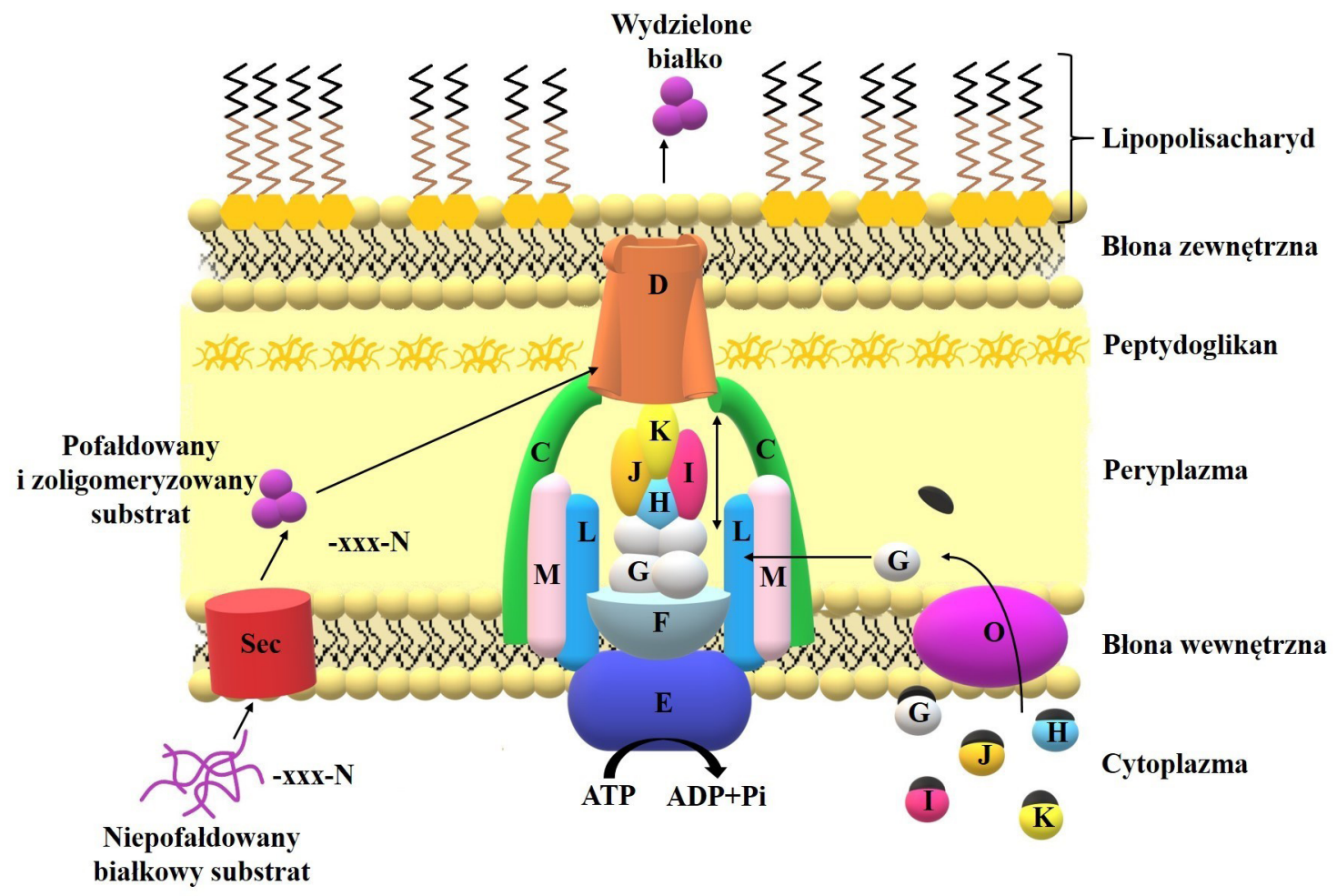

Rycina 1. Schemat funkcjonowania II systemu sekrecji L. pneumophila. Wydzielane białka zawierające sekwencję sygnalną (-xxx-N) są translokowane przez błonę wewnętrzną za pomocą głównego szlaku sekrecyjnego Sec. W peryplazmie sekwencja sygnalna zostaje uwolniona, białko ulega pofałdowaniu do struktury trzeciorzędowej, a następnie zostaje wydzielone do przestrzeni pozakomórkowej przez aparat T2SS. Komponent E systemu T2SS mający aktywność cytoplazmatycznej ATPazy wytwarza energię wymaganą do translokacji białek przez pory sekrecyjne membrany zewnętrznej (komponent D); opracowany na podstawie [6, 29, 43] 
peptyd sygnałowy na końcu aminowym, odpowiedzialny za kierowanie odpowiednich białek do związanej z błoną translokazy Sec [44]. Translokacja błonowa eksportowanych szlakiem Sec białek zachodzi w sposób kotranslacyjny bądź posttranslacyjny [45]. W eksporcie kotranslacyjnym białka prekursorowe mające wysoce hydrofobowy peptyd sygnałowy są rozpoznawane przez cząstkę rozpoznającą sygnał (SRP) już podczas ich syntezy na rybosomie. Następnie kompleks rybosom-powstający łańcuch (RNC) jest kierowany do związanego z błoną receptora SRP (FtsY), po czym następuje przeniesienie kompleksu RNC do porów translokacyjnych, które składają się z integralnych białek błonowych SecYEG. Po związaniu RNC z cytoplazmatyczną stroną kanału SecYEG syntetyzowane na rybosomie białko eksportowane jest bezpośrednio do porów translokacyjnych [46]. W przypadku eksportu posttranslacyjnego białka prekursorowe o mniej hydrofobowych peptydach sygnałowych są w pełni syntetyzowane na rybosomach i po ich uwolnieniu wchodzą w interakcję z białkami oddziałującymi potranslacyjnie (PiP), takimi jak m.in. specyficzny chaperon ukierunkowany na SecB [47], które chronią translokowane białka przed agregacją i utrzymują je w stanie niesfałdowanym, właściwym dla tego typu eksportu. Białka prekursorowe są następnie dostarczane do odpowiednej translokazy i stopniowo „przepychane” przez pory SecYEG za pośrednictwem ATPazy SecA [48]. Związany z SecYEG kompleks składający się z SecD i SecF również stanowi „siłę ciągnącą" dla ulegającego translokacji łańcucha polipeptydowego [49]. Podczas lub krótko po przemieszczeniu substratu przez błonę peptyd sygnałowy jest usuwany przez peptydazę sygnałową, a dojrzałe białko jest uwalniane na zewnątrz błony cytoplazmatycznej [50].

Alternatywnym szlakiem eksportu białek, transportującym substraty w stanie całkowicie sfałdowanym lub oligomerycznym, jest szlak Tat, dla którego charakterystyczna jest obecność pary podwójnej argininy w peptydach sygnałowych substratów [51]. Translokaza Tat Gram-ujemnych i Gram-dodatnich bakterii o dużej zawartości par $G+C$ składa się z następujących białek: TatA, TatB i TatC, podczas gdy translokaza składająca się wyłącznie z TatA i TatC występuje u Gram-dodatnich bakterii o niskiej zawartość par G+C [52, $53,54]$. W takim przypadku białko TatA pełni podwójną funkcję zarówno jako TatA, jak i przejmując również rolę TatB [55, 56]. Sfałdowane białko prekursorowe wiąże się z receptorem substratu obecnym w błonie cytoplazmatycznej, który tworzą białka: TatB oraz TatC (lub przez dwufunkcyjne białko TatA) $[57,58]$. Następnie multimetry TatA są rekrutowane w sposób zależny od siły protonowej do kompleksu receptor-substrat, za pośrednictwem którego substrat jest przemieszczany przez por o odpowiednim rozmiarze składający się ze zmiennej liczby cząsteczek TatA lub przez osłabiony fragment błony w pobliżu kompleksu receptor-substrat, indukowany przez TatA [59, 60, 61]. Ostatecznie peptyd sygnałowy jest usuwany przez peptydazę sygnałową, a dojrzałe białko jest uwalniane po zewnętrznej stronie błony komórkowej [62].

W drugim etapie translokacji białek, substraty przechodzą przez błonę zewnętrzną dzięki specjalnemu kompleksowi białek, który ewolucyjnie wykazuje podobieństwo do bakteryjnych pilusów typu IV. Substraty przeznaczone do wydzielania są rozpoznawane przez aparat T2SS, a następnie, wykorzystując energię generowaną na błonie wewnętrznej, pseudopilus działa podobnie do tłoka przepychającego białka przez pory zbudowane z sekretyny $[4,63,64]$. Prawdopodobnie białka przeznaczone do wydzielania za pośrednictwem T2SS są rozpoznawane przez aparat sekrecyjny za pomocą białek T2S D oraz T2S C [43]. Unikalne cechy molekularne, dzięki którym aparat identyfikuje dane białko jako substrat T2SS, nie są znane, ale przypuszcza się, że obejmują ich trzeciorzędową strukturę, a rozpoznanie substratu może zachodzić również na podstawie wielu niezależnych oddziaływań substratów z elementami składowymi aparatu $[65,66]$.

\section{Geny kodujące białka II systemu sekrecji L. pneumophila}

Geny kodujące T2SS L. pneumophila znajdują się w kilku różnych loci chromosomu bakteryjnego (ryc.2). Cecha ta odróżnia T2SS tego gatunku od większości innych mikroorganizmów, które zawierają geny T2SS kodowane w jednym operonie. Analiza sekwencji promotora i mapowanie miejsca startu transkrypcji L. pneumophila szczepu Paris

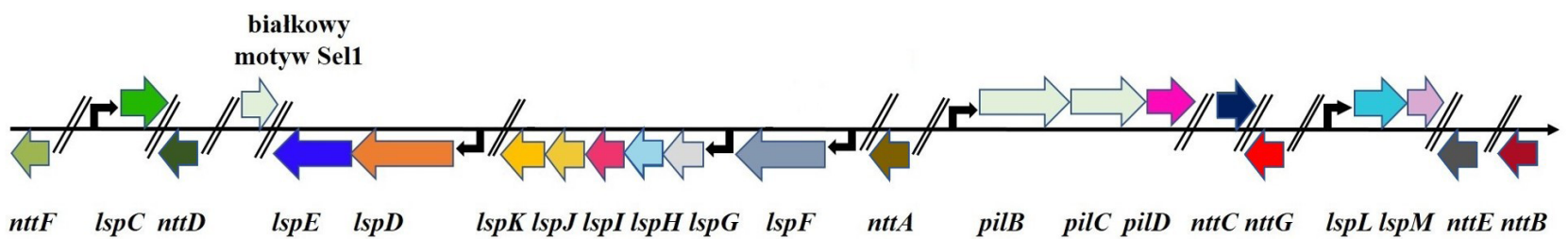

Rycina 2. Schemat rozmieszczenia genów kodujących białka II systemu sekrecji L. pneumophila szczep 130; opracowany na podstawie [29] 
wykazały, że gen IspF jest monocistronowy, podczas gdy inne geny Isp są współtranskrybowane z innymi genami [6].

Pierwszym zidentyfikowanym genem II systemu sekrecji L. pneumophila był gen pilD, który koduje pseudopilinową peptydazę PilD (T2S O) [67]. Mutanty defektywne w syntezie białka PilD nie są zdolne do wydzielania białek [68]. W genomie L. pneumophila szczepu Philadelphia-1 wykazano obecność klastra genów IspFGHIJK, który koduje białka T2S F, -G, -H, -I, -J oraz -K [69]. Inaktywacja genu IspGH powodowała zahamowanie sekrecji białek. W dalszych badaniach $L$. pneumophila szczep 130b wykazano obecność loci kodującego T2S D i E (IspDE), C (IspC) oraz L i M
(IspLM), a analiza mutacyjna genu IspDE potwierdziła ich rolę w wydzielaniu białek [70, 71]. Opublikowanie całego genomu L. pneumophila szczepów należących do serogrupy 1: Philadelphia-1, Paris oraz Lens potwierdziło występowanie w genomie tego gatunku kompletnego systemu T2SS [5, 72, 73, 74]. Analizy porównawcze homologii sekwencji genów wykazały, że geny kodujące T2SS obecne są nie tylko wśród innych serogrup L. pneumophila, ale także u innych gatunków bakterii Legionella [71].

Tabela 1. Substraty II systemu sekrecji L. pneumophila

\begin{tabular}{|c|c|c|c|}
\hline Substrat T2SS & Aktywność enzymatyczna & Podobieństwo do białek eukariotycznych & Piśmiennictwo \\
\hline AmiA & amidaza & & [75] \\
\hline CelA & endoglukanaza & & [77] \\
\hline ChiA & chitynaza & & [75] \\
\hline GamA & glukoamylaza & + & [78] \\
\hline LapA & aminopeptydaza hydrolizująca Leu, Tyr, Phe, Val, lle, Met, Asp & + & [76] \\
\hline LapB & aminopeptydaza hydrolizująca Lys i Arg & + & [79] \\
\hline Lcl & białko kolagenopodobne & + & [80] \\
\hline LegP & proteaza & + & [75] \\
\hline LipA & lipaza monoacyloglicerolowa & & [81] \\
\hline LipB & lipaza triacyloglicerolowa & & [81] \\
\hline LirB & cis-trans-izomeraza peptydylo-prolinowa & & [82] \\
\hline Map & kwaśna fosfataza wrażliwa na działanie winianu & + & [83] \\
\hline $\mathrm{NttA}$ & nowe białko & & [84] \\
\hline NttB & nowe białko, peptydaza z rodziny $\mathrm{C} 1$ & & [84] \\
\hline $\mathrm{NttC}$ & nowe białko & & [84] \\
\hline $\mathrm{NttD}$ & nowe białko & & [75] \\
\hline NttE & nowe białko & & [75] \\
\hline NttF & nowe białko & & [75] \\
\hline $\mathrm{NttG}$ & nowe białko, Virk-podobne & & [75] \\
\hline PlaA & lizofosfolipaza A & & [85] \\
\hline PlaC & transferaza glicerofosfolipid: cholesterol (GCAT), fosfolipaza A & & [87] \\
\hline PlcA & fosfolipaza C & + & [81] \\
\hline PlcB & fosfolipaza C & + & [88] \\
\hline ProA & metaloproteaza & & [75] \\
\hline SrnA & rybonukleaza T2 & & [89] \\
\hline
\end{tabular}




\section{Białka II systemu sekrecji L. pneumophila}

System sekrecji typu II L. pneumophila odpowiada za sekrecję co najmniej 25 białek, w tym wielu enzymów oraz białek unikalnych bakterii z rodzaju Legionella (tabela) [23, 75, 76]. Większość zidentyfikowanych efektorów L. pneumophila występuje również u innych gatunków należących do rodzaju Legionella, co wskazuje na ich główną rolę w ekologii i patogenezie tych bakterii [6].

$\mathrm{Na}$ podstawie analizy utraty różnego rodzaju aktywności enzymatycznych w supernatantach pochodzących z hodowli mutantów w genach Isp L. pneumophila zidentyfikowano: kwaśną fosfatazę wrażliwą na inhibicję winianem (Map), fosfolipazy C (PIcB, PlcA), lizofosfolipaze A (PlaA), acylotransferaze glicerofosfolipid: cholesterol - GCAT (PlaC), lipazy mono- i triacyloglicerolowe (LipA, LipB) rybonukleazę (SrnA) czy metaloproteazę (ProA) [81, 83, $85,86,87,89]$. Badania te uzupełnity analizy proteomiczne, które wykazały obecność aminopeptydaz, działających na aminopeptydy leucyny, fenyloalaniny i tyrozyny (LapA) lub substraty zawierające lizynę i argininę (LapB) [79]. Do białek wydzielanych za pomocą T2SS $L$. pneumophila należą również amidazy, proteaza cysteinowa oraz endoglukanazy [75].

\section{Białka o aktywności lipolitycznej}

Do enzymów o potencjale lipolitycznym wydzielanych za pomocą II systemu sekrecji L. pneumophila należą: fosfolipazy C (PIcA, PlcB), lizofosfolipaza A (PlaA) oraz acylotransferaza PlaC. Główną fosfolipazą $L$. pneumophila jest należąca do rodziny hydrolaz GDSL lizofosfolipaza A, która zawiera katalityczną triadę złożoną z Ser, Asp, His [90]. Hydrolaza PlaA powoduje uwolnienie kwasów tłuszczowych z fosfolipidów błony fagosomów zawierających $L$. pneumophila. W przypadku braku obecności efektora systemu IVB - SdhA, PlaA destabilizuje błonę komórkową wakuoli LCV, co może prowadzić do śmierci komórki gospodarza [90, 91, 92].

Acylotransferaza PlaC, podobnie jak PlaA, należy do rodziny hydrolaz GDSL. Aktywność tego enzymu jest wykrywana w supernatancie hodowli $L$. pneumophila. Białko jest aktywowane $z$ udziałem metaloproteazy ProA, która powoduje rozszczepienie acylotransferazy między aminokwasami w pozycji 343 i 388 . Enzym aktywowany jest przez otwarcie lub zmniejszenie długości pętli disiarczkowej. Analiza mutantów L. pneumophila defektywnych w syntezie PlaC wykazała, że enzym ten odpowiada za przenoszenie kwasu palmitynowego z cząsteczki donorowej diacylofosfolipidu na cholesterol oraz ergosterol, który jest typowym lipidem błon pierwotniaków, grzybów i glonów. Białko PlaC L. pneumophila wykazuje homologię $\mathrm{z}$ acylotransferazą
SatA patogenu ryb Aeromonas salmonicida. Fosfolipazy PIcA oraz PlcB hydrolizują wyłącznie fosfatydyloglicerol (PG). Enzymy te są bezpośrednio lub pośrednio aktywowane za pomocą metaloproteazy ProA oraz jonów $\mathrm{Zn}^{2+}$. Fosfolipazy PlcA oraz PIcB mogą być zarówno eksportowane przez T2SS, jak również występować w postaci związanej ze strukturami pęcherzyków membrany zewnętrznej [90, 93].

Główną funkcją fosfolipaz wydzielanych za pomocą II systemu sekrecji jest bezpośrednia hydroliza wiązań estrowych i uwalnianie kwasów tłuszczowych z pozycji sn-1 i sn-2 struktury fosfolipidów występujących w błonach eukariotycznego gospodarza, czego skutkiem jest utrata ich integralności. Ponadto L. pneumophila wykorzystuje fosfolipazy do degradacji fosfolipidów wchodzących w skład surfaktantu pokrywającego pęcherzyki płucne, co zaburzało czynności narządu, powodując jego uszkodzenia. Produkty reakcji katalizowanych przez fosfolipazy, takie jak 1,2-diacyloglicerol, kwasy tłuszczowe (zwłaszcza kwas arachidonowy) czy lizofosfatydylocholina, mogą pełnić rolę mediatorów pośredniczących w manipulowaniu sygnalizacją komórkową gospodarza, jak również wywoływaniu lub tłumieniu stanu zapalnego bądź procesów apoptozy [94].

\section{Enzymy zaangażowane w pozyskiwanie substancji pokarmowych}

Bakteryjne białka enzymatyczne LapA, ProA, PlaC oraz SrnA trawiąc makrocząsteczki obecne w wakuoli LCV gospodarza, pośredniczą w pozyskiwaniu substancji pokarmowych (aminokwasów, nukleotydów, fosforanów) niezbędnych do wewnątrzkomórkowego namnażania się L. pneumophila [76, 95].

Aminopeptydaza LapA jest zbudowana $z$ dwóch asymetrycznych cząsteczek o łącznej masie około $44 \mathrm{kDa}$. Na N-końcu tego białka występuje charakterystyczna domena PA, która obejmuje miejsce aktywne oraz kieszeń wiążącą substrat. Enzym ten wykazuje zdolność do rozszczepiania substratów, takich jak: aminopeptydy leucyny, fenyloalaniny oraz tyrozyny, a także alaniny, asparaginianu, glicyny, izoleucyny, lizyny, metioniny, seryny i waliny. Większość substratów tego enzymu charakteryzuje obecność niepolarnych aminokwasów docelowych, ale cięcie aminopeptydów asparaginianu, lizyny, seryny i tyrozyny, świadczy o dużej swoistości substratowej tego enzymu [76].

Metaloproteaza ProA oraz rybonukleaza SrnA odgrywają główną rolę w procesie zakażenia pierwotniaków. Mutanty pozbawione obu białek były niezdolne do zakażania ameb, a defekt ten był silniejszy niż odpowiadający pojedynczym mutacjom w genach kodujących białka ProA lub SrnA, co wskazuje na synergistyczne działanie translokowanych białek w procesie zakażania komórek gospodarza [79, 89]. 
Białko ProA oraz potencjalnie inne efektory T2SS mogą się przemieszczać z wakuoli LCV do cytozolu zakażonej komórki Acanthamoeba castellanii, gdzie mogą oddziaływać na różnego rodzaju cele komórkowe [41]. Metaloproteaza ProA ulega również translokacji do cytozolu ludzkich makrofagów, gdzie wiąże się $z$ błoną wakuoli LCV. Białko to jest wykrywalne po 10 godzinach od zakażenia makrofagów, tj. mniej więcej w połowie wewnątrzkomórkowego cyklu bakterii. Natomiast tego typu translokacja nie występowała w mysich makrofagach. Z wakuoli LCV do cytozolu makrofagów przemieszcza się również białko ChiA, ale za pośrednictwem odmiennego mechanizmu niż białko ProA, u podstaw którego leży półprzepuszczalność membrany LCV [41]. Białko ProA rozkłada transferynę gospodarza i w ten sposób pośredniczy w asymilacji żelaza przez $L$. pneumophila. Enzym ten również degraduje cytokiny uwalniane podczas zakażenia $L$. pneumophila, dzięki czemu bakterie uciekają spod kontroli układu odpornościowego gospodarza [6].

Białko SrnA o masie cząsteczkowej $38 \mathrm{kDa}$ należy do rodziny T2 rybonukleaz. Supernatanty pochodzące z hodowli mutantów z inaktywowanym genem srnA nie wykazywały aktywności RNazy, co wskazuje, że SrnA jest główną wydzielaną rybonukleazą $L$. pneumophila. Mutanty defektywne w syntezie tego enzymu charakteryzowały się prawidłową morfologią kolonii na sztucznym podłożu. Mutanty te były również zdolne do namnażania się w makrofagach linii U937, natomiast miały upośledzoną zdolność do wzrostu $w$ amebach Vermamoeba vermiformis [89]. Pozyskiwanie nukleotydów i/lub fosforanów w wyniku degradacji RNA eukariotycznego gospodarza za pośrednictwem enzymu SrnA może wpływać na zmianę funkcjonowania komórki gospodarza.

Do białek wydzielanych za pomocą II systemu sekrecji należą również proteazy oraz peptydazy, które umożliwiają pozyskiwanie aminokwasów. Aminokwasy, przede wszystkim cysteina, są głównym źródłem węgla i energii dla $L$. pneumophila [96]. Obecność w sekretomie tych bakterii chitynazy (ChiA) oraz endoglukanazy sugeruje, że $L$. pneumophila jest równieżzdolna do degradacji i wykorzystania złożonych węglowodanów. Aktywność ChiA jest niezbędna do przeżycia L. pneumophila w płucach gospodarza. ChiA jest dwufunkcyjnym enzymem, którego C-końcowa domena dodatkowo ma aktywność peptydazy zależnej od jonów $\mathrm{Zn}^{2+}$ wobec ssaczych białek mucynopodobnych: MUC5AC oraz inhibitora C1-esterazy. Enzym ten trawiąc mucynę, ułatwia przejście L. pneumophila przez błonę śluzową pęcherzyków płucnych, a także moduluje działanie układu dopełniacza gospodarza [97].

\section{Pozostałe białka wydzielane za pomocą II systemu} sekrecji L. pneumophila

Za pomocą II systemu sekrecji L. pneumophila wydzielane są również białka NttA, NttC, NttD, a także NttE, których obecność jest niezbędna do prawidłowego przebiegu cyklu wewnątrzkomórkowego namnażania się bakterii w komórkach pierwotniaków. Substraty NttA i NttD wpływają na zdolność $L$. pneumophila do wewnątrzkomórkowej replikacji w komórkach A. castellanii, natomiast nie są niezbędne podczas wzrostu w pierwotniakach $V$. vermiformis oraz Naegleria lovaniensis. Substraty te nie wpływały również na zdolność $L$. pneumophila do namnażania się w komórkach makrofagów linii U937. Białko NttA jest zdolne do wiązania oraz modyfikowania fosforylowanych fosfoinozytoli, które uczestniczą w regulowaniu szlaków sygnalnych oraz procesów transportu pęcherzykowego w komórkach gospodarza. Przypuszczalnie substrat NttA ulega transportowi do cytoplazmy komórki, następnie wiąże się z lipidami tworzącymi membranę wakuoli LCV i oddziałuje na wczesne etapy wewnątrzkomórkowej infekcji gospodarza. Mutacja w genach kodujących małe monomeryczne białko NttC zaburza proces infekcji komórek $V$. vermiformis oraz Willaertia magna, a nie wpływa na namnażanie się $w$ komórkach $N$. lovaniensis oraz $A$. castellanii. Substrat NttE jest wymagany do prawidłowego procesu zakażenia A. castellanii i V. vermiformis [98].

Wśród efektorów T2SS $L$. pneumophila wykazano również obecność białek: IcmX, LvrE oraz białka VirKpodobnego. Podczas gdy IcmX i LvrE są związane z układem wydzielniczym typu IV L. pneumophila, białko Virk jest charakterystyczne dla systemu sekrecji typu IV Agrobacterium tumefaciens, co sugeruje związek między wydzielaniem typu II i typu IV. Chociaż białka IcmX, LvrE i białko VirK-podobne są kodowane przez geny systemu wydzielniczego typu IV, sekrecja tych białek może zachodzić przez system T2SS [43]. Niektóre efektory mogą być zatem wydzielane za pomocą więcej niż jednego systemu sekrecji, przy czym warunki środowiskowe (kontakt z pierwotniakami lub makrofagami człowieka) mogą potencjalnie determinować, który szlak lub szlaki zostaną zaangażowane. Na przykład proteinaza cynkowa (LegP), która jest homologiem eukariotycznej proteinazy, mimo że $w$ analizie proteomicznej została zdefiniowana jako zależna od T2SS, translokowana jest również za pośrednictwem systemu sekrecyjnego typu IV podczas wzrostu $L$. pneumophila w makrofagach $[43,99]$.

Unikalną cechą genomu L. pneumophila jest obecność dużej liczby genów, które kodują wiele białek podobnych do białek eukariotycznych, np. zawierających powtórzenia bogate w motyw ankiryny lub leucyny $[72,100,101,102,103]$. Efektory systemu sekrecji typu II L. pneumophila są podobne do substratów obecnych w komórkach pierwotniaków czy 
nawet grzybów. Wysoki stopień podobieństwa białek II systemu sekrecji wykazano również w przypadku białek występujących u bakterii z rodzaju Aquicella [6]. Na przykład proteinaza cynkowa LegP oraz kwaśna fosfataza Map maja wysoki stopień podobieństwa do białek eukariotycznych $[75$, 83]. Innym białkiem, które wykazuje homologię do białek eukariotycznych jest substrat T2SS - Lcl, zawierający powtórzenia podobne do kolagenu [75].

Pięć spośród wszystkich zidentyfikowanych substratów T2SS L. pneumophila nie było podobnych do żadnego znanego białka lub domeny białkowej, co może wskazywać, że mają całkiem nowe aktywności [75]. Analizy bioinformatyczne genomu L. pneumophila szczepu Philadelphia-1 wykazały obecność co najmniej 60 domniemanych substratów T2SS [75]. Przypuszcza się, że w miarę sekwencjonowania genomów większej liczby gatunków pierwotniaków, które są naturalnym gospodarzem bakterii z rodzaju Legionella, wiele substratów T2SS obecnie określanych jako „nowe”, może wykazywać podobieństwo do białek eukariotycznych [6].

\section{Znaczenie II systemu sekrecji w przeżyciu L. pneumophila w środowisku wodnym}

Głównym mechanizmem pozwalającym bakteriom z rodzaju Legionella na przetrwanie $w$ środowisku wodnym jest ich bytowanie w ochronnej strukturze biofilmów przytwierdzonych do biotycznego lub abiotycznego podłoża. Wykazano, że populacje $L$. pneumophila osiągające znaczną gęstość mogą hamować wzrost innych bakterii należących zarówno do tego samego, jak innego gatunku rodzaju Legionella, zapobiegając dołączeniu kolejnych mikroorganizmów do dominującej kolonii bakteryjnej. U podstaw tego zjawiska leży zdolność bakterii do wydzielania cząsteczek kwasu homogentyzynowego. Kwas ten łącząc się z tlenem, tworzy brązowy pigment - piomelaninę, który oprócz tego, że chroni pałeczki z rodzaju Legionella przed fotouszkodzeniami i uczestniczy w pozyskiwaniu żelaza, ma również właściwości toksyczne, przy czym obecność tlenu w środowisku jest warunkiem koniecznym dla toksyczności wydzielanego przez bakterie kwasu. Reaktywny związek pośredni, powstający w trakcie przekształcania kwasu homogentyzynowego do piomelaniny, prawdopodobnie odpowiada za jego właściwości hamujące wzrost bakterii. Mutanty L. pneumophila, które nie hamują wzrostu innych bakterii z tego samego rodzaju, nie syntetyzują kwasu homogentyzynowego. Wydzielanie inhibitora wzrasta, gdy bakterie znajdują się $\mathrm{w}$ fazie stacjonarnej, dla której typowa jest duża gęstość kolonii bakteryjnej [104].

System T2SS umożliwia tworzenie biofilmu oraz długotrwałe przeżycie bakterii $w$ jego strukturach. Mutanty
L. pneumophila pozbawione substratu Lcl zależnego od T2SS nie są zdolne do tworzenia biofilmu na powierzchniach szklanych lub polisterynowych w statycznych hodowlach [105]. Natomiast mutanty defektywne w syntezie peptydazy prepilinowej nie mogą przetrwać $w$ biofilmie $w$ dynamicznym układzie komórkowym [106]. System prawdopodobnie ułatwia rozprzestrzenianie się $L$. pneumophila w środowisku, na co pośrednio wskazuje zdolność do syntezy surfaktantu, który umożliwia ślizganie się bakterii po półstałym agarze [107].

System sekrecji typu II odgrywa przede wszystkim decydującą rolę w przeżyciu L. pneumophila w ekosystemach wodnych $w$ niskich temperaturach, zarówno w postaci planktonicznej, jak i we wnętrzu komórki gospodarza. Niska temperatura wody nie sprzyja wewnątrzkomórkowej replikacji pałeczek Legionella ze względu na zmniejszenie ilości dostępnych składników odżywczych oraz stres oksydacyjny, który zwiększa się wraz ze spadkiem temperatury wody. Zaburzenia funkcjonowania II systemu sekrecji powodują dezintegrację błony komórkowej bakterii, wyciek zawartości komórki oraz jej lizę. Mutacje w genach kodujących sekretynę błony zewnętrznej typu II (IspD), ATPazę błony wewnętrznej $(I s p E)$, białkową platformę błony wewnętrznej $(I s p F)$ oraz peptydaze pseudopiliny (pilD) wpływają na znaczne zredukowanie przeżywalności $L$. pneumophila sg1 szczep $130 \mathrm{~b} w$ wodzie wodociągowej w temperaturze $17^{\circ} \mathrm{C}$ w porównaniu do komórek typu dzikiego. Wykazano, że proces inicjacji transkrypcji genu kodującego peptydazę prepiliny $L$. pneumophila znacznie wzrasta w niskiej temperaturze [108]. W supernatancie płynnej hodowli $L$. pneumophila szczep $130 \mathrm{~b}$ prowadzonej w temperaturze 12 i $17^{\circ} \mathrm{C}$ wykryto obecność peptydoilo-prolilo izomerazy PipB, która może wpływać na zwiększenie przeżywalności bakterii w niskiej temperaturze przez katalizowanie izomeryzacji białek sekrecyjnych typu II [82, 109].

Białka II systemu sekrecji uczestniczą w procesie zakażania wolno żyjących ameb z rodzajów Acanthamoeba, Naegleria, Vermamoeba oraz Willaertia [84, 110]. Mutanty Isp L. pneumophila szczepu Filadelfia wykazywały ograniczony wzrost w amebach, a defekt ten był jeszcze bardziej wyraźny, jeśli hodowlę ameb i zmutowanego szczepu prowadzono w temperaturze $22-25^{\circ} \mathrm{C}$ [109]. Badania przeprowadzone na mutantach niezdolnych do wytwarzania różnych białek II systemu sekrecji wykazały, że substraty tego systemu mogą odgrywać znaczącą rolę $w$ kształtowaniu zakresu pierwotniaczego gospodarza. Mutant w genie $n t t A$ nie zakażał A. castellanii, ale dobrze namnażał się w komórkach $V$. vermiformis i $N$. lovaniensis, natomiast mutanty plaC, proA i srnA były upośledzone w zakażaniu $V$. vermiformis i $N$. lovaniensis, ale namnażały się w A. castellanii [110]. 
Rola II systemu sekrecji L. pneumophila w patogenezie choroby legionistów

$\mathrm{Na}$ istotne znaczenie II systemu sekrecji L. pneumophila w rozwoju zakażenia wskazują badania, które wykazały, że mutanty pozbawione białek (LspDE, LspF, LspG, LspK, LspO/pilD) tego systemu charakteryzują się ograniczonym wzrostem zarówno w mysich makrofagach alweolarnych, jak i makrofagach szpiku kostnego oraz w ludzkich makrofagach linii U937 i THP-1 [68, 70, 71, 111]. Na początku wewnątrzkomórkowego cyklu zakażania makrofagów substraty II systemu sekrecji $L$. pneumophila przemieszczają się z wakuoli LCV w pobliżu cytoplazmy makrofagów. Badania przebiegu infekcji zarówno ludzkich, jak i mysich makrofagów wykazały, że białka II systemu sekrecji nie są zaangażowane w proces wnikania L. pneumophila do wnętrza komórki gospodarza ani unikania fuzji wakuoli zawierającej bakterie z lizosomami, natomiast są niezbędne do optymalnego przyłączenia białka Rab1B z błoną wakuoli i wewnątrzkomórkowego namnażania się między 8 a 12 godziną od zakażenia [112].

Białka systemu T2SS mają również wpływ na modulację odpowiedzi odpornościowej gospodarza. Mutanty z defektywnym systemem T2SS uzyskane z wirulentnych szczepów L. pneumophila słabiej indukowały wytwarzanie IL6, TNF- $\alpha$, IL-1 oraz IL-8 w zakażonych makrofagach linii U937 oraz w komórkach nabłonkowych A549 [88]. Te prozapalne cytokiny modulują zarówno miejscową, jak i ogólnoustrojową odpowiedź zapalną, pomagają w rekrutacji i aktywacji leukocytów, sprzyjając tym samym dalszemu wytwarzaniu cytokin oraz zwiększonej aktywności bakteriobójczej. Tłumienie wytwarzania cytokin przez zakażone L. pneumophila makrofagi i komórki nabłonka przyczynia się do zmniejszonego nacieku komórek zapalnych, a to pozwala na przedłużone namnażanie się bakterii w płucach [88]. Spadek indukcji prozapalnych cytokin (IL-6) występował również po zakażeniu makrofagów linii THP-1 i monocytów krwi obwodowej, ale nie występował w zakażeniach mysich makrofagów. Mechanizm spadku indukcji prozapalnych cytokin pod wpływem efektorów T2SS jest związany z tłumieniem transdukcji sygnału gospodarza za pośrednictwem kinaz MAPK i czynnika transkrypcji NF-kB. Inne badania przeprowadzone na mutantach pozbawionych genów MyD88 lub receptora TLR 2 wykazały niższy spadek wytwarzania IL-6 w zakażonych tymi mutantami makrofagach w porównaniu do zakażenia szczepem dzikim, co wskazuje na udział tych szlaków sygnalnych w regulacji odpowiedzi komórkowej na efektory T2SS L. pneumophila [113].

Brak tłumiącego wpływu białek T2SS na poziom indukcji prozapalnych cytokin w przypadku wewnątrzkomórkowej infekcji mysich makrofagów wskazuje na odmienne rozpoznawanie u ludzi i myszy wzorców molekularnych PAMPs.
Ludzki szlak TLR2 i mysi TLR2 wykazują 84\% podobieństwa aminokwasów w domenach wewnątrzkomórkowych, przy czym są jedynie w $65 \%$ podobne w domenach zewnątrzkomórkowych, co może być przyczyną różnej zdolności rozpoznawania ligandów [113, 114].

Mutanty L. pneumophila defektywne w syntezie białek II systemu sekrecji słabo namnażały się w komórkach płuc i nie wywoływały choroby na mysim A/J modelu zapalenia płuc. Badanie surowicy krwi otrzymanej z myszy zakażonych dzikim szczepem L. pneumophila wykazały, że białka zależne od T2SS ulegają ekspresji in vivo [71]. Ponieważ w badaniach in vitro infekcji makrofagów i komórek nabłonkowych układu oddechowego mutanty te wykazywały nieznaczne upośledzenie zdolności wewnątrzkomórkowego namnażania, wskazuje to, że system ten może modulować przebieg innych procesów komórkowych gospodarza [88]. Fosfolipazy wydzielane za pomocą T2SS biorą udział w tworzeniu porów w błonie fagosomu i w ten sposób umożliwiają ucieczkę bakterii z wyeksploatowanej komórki gospodarza [115].

Substraty T2SS są obecne również w pęcherzykach błony zewnętrznej uwalnianych z powierzchni L. pneumophila. Wynika to $z$ obecności białek efektorowych w peryplazmie przed zakończeniem procesu wydzielania, a także w niektórych przypadkach z ich występowania na powierzchni komórki bakteryjnej [116].

\section{Podsumowanie}

Naturalnym środowiskiem występowania Legionella są słodkowodne zbiorniki wodne, w których stanowią zaledwie około $1 \%$ ogólnej liczby bakterii, ponieważ nie są w stanie konkurować z innymi szybko rosnącymi drobnoustrojami o pokarm i tlen, ze względu na ich wysokie wymagania odżywcze, możliwe do spełnienia tylko wewnątrz komórki eukariotycznego gospodarza. W procesie adaptacji bakterii do tych skrajnie odmiennych warunków, jakimi są środowisko wodne ubogie w składniki odżywcze do środowiska wnętrza komórki gospodarza, zasobnego w pokarm, istotną rolę odgrywają białka wydzielane za pomocą II systemu sekrecji. Białka te determinują zdolność $L$. pneumophila do przeżycia zarówno w postaci planktonicznej, jak i w strukturach biofilmu w wodzie o niskiej temperaturze. Substraty T2SS umożliwiają pałeczkom Legionella zakażenie różnych gatunków pierwotniaków, które chronią bakterie przed niekorzystnymi fizyko-chemicznymi czynnikami środowiska, innymi drobnoustrojami oraz stwarzają dogodną, bogatą w składniki pokarmowe niszę replikacyjną, w ten sposób przyczyniając się do rozsiewania tych bakterii. Odzwierciedleniem wspólnej ewolucji ze słodkowodnymi pierwotniakami jest obecność w genomie L. pneumophila dużej liczby genów kodujących białka bardzo podobnych do białek eukariotycznych, jak 
np. proteinaza cynkowa LegP oraz kwaśna fosfataza Map, które są wydzielane za pomocą II systemu sekrecji. Białka tego systemu umożliwiają również zakażanie makrofagów alweolarnych, makrofagów szpiku kostnego myszy oraz ludzkich makrofagów linii U937 i THP-1. W procesie wewnątrzkomórkowego namnażania się L. pneumophila niezbędne jest pozyskiwanie substancji pokarmowych, które jest możliwe dzięki wydzielaniu białek enzymatycznych LapA, ProA, PlaC oraz SrnA, odpowiedzialnych za trawienie makrocząsteczek gospodarza. Ponadto fosfolipazy wydzielane za pomocą T2SS rozkładają lipidy wchodzące w skład surfaktantu pęcherzyków płucnych, co powoduje uszkodzenia tkanki płucnej w przebiegu choroby legionistów. Natomiast chitynaza ułatwia przejście bakterii L. pneumophila przez błonę śluzową pęcherzyków płucnych, trawiąc mucynę. T2SS odpowiada również za hamowanie mechanizmów wrodzonej odpowiedzi odpornościowej gospodarza na zakażenie L. pneumophila. System sekrecji typu II ma podstawowe znaczenie zarówno w ekologii, jak i w patogenezie L. pneumophila, dlatego poznanie funkcji substratów tego systemu może mieć znaczenie w opracowaniu nowych strategii zwalczania tych patogenów.

\section{Wykaz skrótów}

\section{GCAT - C-acetylotransferaza glicyny (glycine} C-acetyltransferase), GDSL - rodzina esteraz/lipaz serynowych (family of serine esterases/lipases), IM - błona wewnętrzna (inner membrane), LCV - wakuola replikacyjna Legionella (Legionella-containing vacuole), MAPK - kinazy białkowe aktywowane mitogenami (mitogen-activated protein kinases), MyD88 - gen 88 pierwotnej odpowiedzi różnicowania szpiku (mieloid differentiation primary response gene 88), NFKB - jądrowy czynnik transkrypcyjny NF kappa B (nuclear factor kappa B), OM - błona zewnętrzna (outer membrane), OMV - pęcherzyk błony zewnętrznej (outer membrane vesicle), PA - N-końcowa domena aminopeptydazy Lap „związana z proteazą" ( $N$-terminal, "protease-associated" LapA aminopeptidase domain), PAMPs - wzorce molekularne związane $\mathrm{z}$ patogenami (pathogen associated molecular patterns), PG - fosfatydyloglicerol (phosphatidylglycerol), PiP - białka oddziałujące potranslacyjnie (post-translational interacting proteins), RNC - kompleks rybosom-powstający łańcuch (ribosome-nascent chain complex), Sec - szlak wydzielania ogólnego (general secretion pathway), SRP cząstka rozpoznająca sygnał (signal recognition particle), Tat - szlak podwójnej translokacji argininy (twin-arginine translocation pathway), TBK1 - kinaza wiążąca TANK 1 (TANK-binding kinase 1), TLRs - receptory Toll-podobne (toll-like receptors), TNF- $\alpha-$ czynnik martwicy nowotworu- $\alpha$ (tumor necrosis factor- $\alpha$ ), T2SS - system sekrecji typu II (type II secretion system).

\section{Konflikt interesów}

Autorki deklarują brak potencjalnych konfliktów interesów.

\section{Piśmiennictwo}

[1] Hayes C.S., Aoki S.K., Low D.A.: Bacterial contact-dependent delivery systems. Annu. Rev. Genet., 2010; 44: 71-90

[2] So E.C., Mattheis C., Tate E.W., Frankel G., Schroeder G.N.: Creating a customized intracellular niche: Subversion of host cell signaling by Legionella type IV secretion system effectors. Can. J. Microbiol., 2015; 61: 617-635

[3] Brzostek K., Karwicka E.: Mechanizmy sekrecji bakterii Gramujemnych - system sekrecji II typu, sekrecja w biogenezie pilusów, autotransport. Post. Mikrobiol., 2006; 45: 135-151

[4] Cianciotto N.P.: Type II secretion and Legionella virulence. Curr. Top. Microbiol. Immunol., 2013; 376: 81-102

[5] Cianciotto N.P.: Type II secretion: A protein secretion system for all seasons. Trends. Microbiol., 2005; 13: 581-588

[6] White R.C., Cianciotto N.P.: Assessing the impact, genomics and evolution of type II secretion across a large, medically important genus: The Legionella type II secretion paradigm. Microb. Genom., 2019; 5: e000273

[7] Cianciotto N.P., White R.C.: Expanding role of type II secretion in bacterial pathogenesis and beyond. Infect. Immun., 2017; 85: e00014-17

[8] Korotkov K.V., Sandkvist M.: Architecture, function, and substrates of the type II secretion system. EcoSal. Plus., 2019; 8: 10.1128/ ecosalplus.ESP-0034-2018

[9] Abdel-Nour M., Duncan C., Low D.E., Guyard C.: Biofilms: The stronghold of Legionella pneumophila. Int. J. Mol. Sci., 2013; 14: 21660-21675

[10] Boamah D.K., Zhou G., Ensminger A.W., O'Connor T.J.: From many hosts, one accidental pathogen: The diverse protozoan hosts of Legionella. Front. Cell. Infect. Microbiol., 2017; 7: 477

[11] Liu X., Boyer M.A., Holmgren A.M., Shin S.: Legionella-infected macrophages engage the alveolar epithelium to metabolically reprogram myeloid cells and promote antibacterial inflammation. Cell Host Microbe, 2020; 28: 683-698.e6

[12] Chaudhry R., Sreenath K., Agrawal S.K., Valavane A.: Legione/la and Legionnaires' disease: Time to explore in India. Indian. J. Med. Microbiol., 2018; 36: 324-333

[13] Ditommaso S., Giacomuzzi M., Arauco Rivera S.R., Raso R., Ferrero P., Zotti C.M.: Virulence of Legionella pneumophila strains isolated from hospital water system and healthcare-associated Legionnaires' disease in Northern Italy between 2004 and 2009 BMC Infect. Dis., 2014; 14: 483 
[14] Gomez-Valero L., Rusniok C., Carson D., Mondino S., PérezCobas A.E., Rolando M., Pasricha S., Reuter S., Demirtas J., Crumbach J. i wsp.: More than 18,000 effectors in the Legionella genus genome provide multiple, independent combinations for replication in human cells. Proc. Natl. Acad. Sci. USA, 2019; 116: 2265-2273

[15] Correia A.M., Ferreira J.S., Borges V., Nunes A., Gomes B., Capucho R., Gonçalves J., Antunes D.M., Almeida S., Mendes A. i wsp.: Probable person-to-person transmission of Legionnaires' disease. N. Engl. J. Med., 2016; 374: 497-498

[16] De Giglio O., Fasano F., Diella G., Lopuzzo M., Napoli C., ApolIonio F., Brigida S., Calia C., Campanale C., Marzella A. i wsp.: Legionella and legionellosis in touristic-recreational facilities: Influence of climate factors and geostatistical analysis in Southern Italy (2001-2017). Environ. Res., 2019; 178: 108721

[17] Surveillance Atlas of Infectious Diseases. http://atlas.ecdc.europa.eu/public/index.aspx (01.11.2020)

[18] Lin S.Y., Chen Y.H., Lu P.L., Tsai Y.M., Chen T.C.: An underestimated co-infection: Swine influenza and pneumonia due to Legionella pneumophila. Am. J. Med. Sci., 2016; 352: 314-316

[19] Faulkner G., Garduño R.A.: Ultrastructural analysis of differentiation in Legionella pneumophila. J. Bacteriol., 2002; 184: 70257041

[20] Fuche F., Vianney A., Andrea C., Doublet P., Gilbert C.: Functional type 1 secretion system involved in Legionella pneumophila virulence. J. Bacteriol., 2015; 197: 563-571

[21] Qin T., Zhou H., Ren H., Liu W.: Distribution of secretion systems in the genus Legionella and its correlation with pathogenicity. Front. Microbiol., 2017; 8: 388

[22] Nakano N., Kubori T., Kinoshita M., Imada K., Nagai H.: Crystal structure of Legionella DotD: Insights into the relationship between type IVB and type II/III secretion systems. PLoS Pathog., 2010; 6: e1001129

[23] White R.C., Truchan H.K., Zheng H., Tyson J.Y., Cianciotto N.P.: Type II secretion promotes bacterial growth within the Legionellacontaining vacuole in infected amoebae. Infect. Immun., 2019; 87 : e00374-19

[24] De Buck E., Maes L., Meyen E., Van Mellaert L., Geukens N., Anné J., Lammertyn E.: Legionella pneumophila Philadelphia-1 tatB and tatC affect intracellular replication and biofilm formation. Biochem. Biophys. Res. Commun. 2005; 331: 1413-1420

[25] Personnic N., Striednig B., Hilbi H.: Quorum sensing controls persistence, resuscitation, and virulence of Legionella subpopulations in biofilms. ISME J., 2021; 15: 196-210

[26] Abby S.S., Cury J., Guglielmini J., Néron B., Touchon M., Rocha E.P.: Identification of protein secretion systems in bacterial genomes. Sci. Rep., 2016; 6: 23080

[27] Costa T.R., Felisberto-Rodrigues C., Meir A., Prevost M.S., Redzej A., Trokter M., Waksman G.: Secretion systems in Gramnegative bacteria: Structural and mechanistic insights. Nat. Rev. Microbiol., 2015; 13: 343-359
[28] Lu C., Korotkov K.V., Hol W.G.: Crystal structure of the full-length ATPase GspE from the Vibrio vulnificus type II secretion system in complex with the cytoplasmic domain of GspL. J. Struct. Biol., 2014; 187: 223-235

[29] Ghosal D., Kim K.W., Zheng H., Kaplan M., Truchan H.K., Lopez A.E., McIntire I.E., Vogel J.P., Cianciotto N.P., Jensen G.J.: In vivo structure of the Legionella type II secretion system by electron cryotomography. Nat. Microbiol., 2019; 4: 2101-2108

[30] Thomassin J.L., Santos Moreno J., Guilvout I., Tran Van Nhieu G., Francetic O.: The trans-envelope architecture and function of the type 2 secretion system: New insights raising new questions. Mol. Microbiol., 2017; 105: 211-226

[31] Filloux A., Voulhoux R.: Multiple structures disclose the secretins' secrets. J. Bacteriol. 2018; 200: e00702-17

[32] Naskar S., Hohl M., Tassinari M., Low H.H.: The structure and mechanism of the bacterial type II secretion system. Mol. Microbiol., 2021; 115: 412-424

[33] Nivaskumar M., Francetic O.: Type II secretion system: A magic beanstalk or a protein escalator. Biochim. Biophys. Acta, 2014; 1843: 1568-1577

[34] Gray M.D., Bagdasarian M., Hol W.G., Sandkvist M.: In vivo cross-linking of EpsG to EpsL suggests a role for EpsL as an ATPase-pseudopilin coupling protein in the Type II secretion system of Vibrio cholerae. Mol. Microbiol., 2011; 79: 786-798

[35] López-Castilla A., Thomassin J.L., Bardiaux B., Zheng W., Nivaskumar M., Yu X., Nilges M., Egelman E.H., Izadi-Pruneyre N., Francetic O.: Structure of the calcium-dependent type 2 secretion pseudopilus. Nat. Microbiol., 2017; 2: 1686-1695

[36] Nunn D.: Bacterial type II protein export and pilus biogenesis: More than just homologies? Trends Cell Biol., 1999; 9: 402-408

[37] Guilvout I., Chami M., Engel A., Pugsley A.P., Bayan N.: Bacterial outer membrane secretin PuID assembles and inserts into the inner membrane in the absence of its pilotin. EMBO J., 2006; 25 : 5241-5249

[38] Viarre V., Cascales E., Ball G., Michel G.P., Filloux A., Voulhoux R.: HxcQ liposecretin is self-piloted to the outer membrane by its N-terminal lipid anchor. J. Biol. Chem., 2009; 284: 33815-33823

[39] Carter T., Buensuceso R.N., Tammam S., Lamers R.P., Harvey H., Howell P.L., Burrows L.L.: The type IVa pilus machinery is recruited to sites of future cell division. mBio, 2017; 8: e02103-16

[40] Yahashiri A., Jorgenson M.A., Weiss D.S.: The SPOR domain, a widely conserved peptidoglycan binding domain that targets proteins to the site of cell division. J. Bacteriol., 2017; 199: e00118-17

[41] Truchan H.K., Christman H.D., White R.C., Rutledge N.S., Cianciotto N.P.: Type II secretion substrates of Legionella pneumophila translocate out of the pathogen-occupied vacuole via a semipermeable membrane. mBio, 2017; 8: e00870-17

[42] Freudl R.: Signal peptides for recombinant protein secretion in bacterial expression systems. Microb. Cell Fact., 2018; 17: 52

[43] Cianciotto N.P.: Many substrates and functions of type II secretion: Lessons learned from Legionella pneumophila. Future Microbiol., 2009; 4: 797-805 
[44] Rusch S.L., Kendall D.A.: Interactions that drive Sec-dependent bacterial protein transport. Biochemistry, 2007; 46: 9665-9673

[45] Denks K., Vogt A., Sacchelaru I., Petriman N.A., Kudva R., Koch H.G.: The Sec translocon mediated protein transport in prokaryotes and eukaryotes. Mol. Membr. Biol., 2014; 31: 58-84

[46] Elvekrog M.M., Walter P.: Dynamics of co-translational protein targeting. Curr. Opin. Chem. Biol., 2015; 29: 79-86

[47] Bechtluft P., Nouwen N., Tans S.J., Driessen A.J.: SecB - a chaperone dedicated to protein translocation. Mol. Biosyst., 2010; 6 : 620-627

[48] Lycklama A., Nijeholt J.A., Driessen A.J.: The bacterial Sec-translocase: Structure and mechanism. Philos. Trans. R. Soc. B. Lond. B Biol. Sci., 2012; 367: 1016-1028

[49] Tsukazaki T., Mori H., Echizen Y., Ishitani R., Fukai S., Tanaka T., Perederina A., Vassylyev D.G., Kohno T., Maturana A.D., Ito K., Nureki O.: Structure and function of a membrane component SecDF that enhances protein export. Nature, 2011; 474: 235-238

[50] Dalbey R.E., Wang P., van Dijl J.M.: Membrane proteases in the bacterial protein secretion and quality control pathway. Microbiol. Mol. Biol. Rev., 2012; 76: 311-330

[51] Palmer T., Berks B.C.: The twin-arginine translocation (Tat) protein export pathway. Nat. Rev. Microbiol., 2012; 10: 483-496

[52] Oertel D., Schmitz S., Freudl R.: A TatABC-type Tat translocase is required for unimpaired aerobic growth of Corynebacterium glutamicum ATCC13032. PLoS One, 2015; 10: e0123413

[53] Sargent F., Stanley N.R., Berks B.C., Palmer T.: Sec-independent protein translocation in Escherichia coli. A distinct and pivotal role for the TatB protein. J. Biol. Chem., 1999; 274: 36073-36082

[54] Simone D., Bay D.C., Leach T., Turner R.J.: Diversity and evolution of bacterial twin arginine translocase protein, TatC, reveals a protein secretion system that is evolving to fit its environmental niche. PLoS One, 2013; 8: e78742

[55] Blaudeck N., Kreutzenbeck P., Müller M., Sprenger G.A., Freudl R.: Isolation and characterization of bifunctional Escherichia coli TatA mutant proteins that allow efficient Tat-dependent protein translocation in the absence of TatB. J. Biol. Chem., 2005; 280 : 3426-3432

[56] Jongbloed J.D., van der Ploeg R., van Dijl J.M.: Bifunctional TatA subunits in minimal Tat protein translocases. Trends Microbiol., 2006; 14: 2-4

[57] Alami M., Lüke I., Deitermann S., Eisner G., Koch H.G., Brunner J., Müller M.: Differential interactions between a twin-arginine signal peptide and its translocase in Escherichia coli. Mol. Cell, 2003; 12: 937-946

[58] Lausberg F., Fleckenstein S., Kreutzenbeck P., Fröbel J., Rose P., Müller M., Freudl R.: Genetic evidence for a tight cooperation of TatB and TatC during productive recognition of twin-arginine (Tat) signal peptides in Escherichia coli. PLoS One, 2012; 7: e39867

[59] Brüser T., Sanders C.: An alternative model of the twin arginine translocation system. Microbiol. Res., 2003; 158: 7-17

[60] Gohlke U., Pullan L., McDevitt C.A., Porcelli I., de Leeuw E., Palmer T., Saibil H.R., Berks B.C.: The TatA component of the twin-arginine protein transport system forms channel complexes of variable diameter. Proc. Natl. Acad. Sci. USA, 2005; 102: $10482-10486$

[61] Mori H., Cline K.: A twin arginine signal peptide and the $\mathrm{pH}$ gradient trigger reversible assembly of the thylakoid $\Delta \mathrm{pH} /$ Tat translocase. J. Cell Biol., 2002; 157: 205-210

[62] Lüke I., Hanford J.I., Palmer T., Sargent F.: Proteolytic processing of Escherichia coli twin-arginine signal peptides by LepB. Arch. Microbiol., 2009; 191: 919-925

[63] Hospenthal M.K., Costa T.R., Waksman G.A.: A comprehensive guide to pilus biogenesis in Gram-negative bacteria. Nat. Rev. Microbiol., 2017; 15: 365-379

[64] Peabody C.R., Chung Y.J., Yen M.R., Vidal-Ingigliardi D., Pugsley A.P., Saier M.H.: Type II protein secretion and its relationship to bacterial type IV pili and archaeal flagella. Microbiology, 2003; 149: 3051-3072

[65] Francetić O., Pugsley A.P.: Towards the identification of type II secretion signals in a nonacylated variant of pullulanase from Klebsiella oxytoca. J. Bacteriol., 2005; 187: 7045-7055

[66] Johnson T.L., Abendroth J., Hol W.G., Sandkvist M.: Type II secretion: From structure to function. FEMS Microbiol. Lett., 2006; 255: $175-186$

[67] Liles M.R., Viswanathan V.K., Cianciotto N.P.: Identification and temperature regulation of Legionella pneumophila genes involved in type IV pilus biogenesis and type II protein secretion. Infect. Immun., 1998; 66: 1776-1782

[68] Liles M.R., Edelstein P.H., Cianciotto N.P.: The prepilin peptidase is required for protein secretion by and the virulence of the intracellular pathogen Legionella pneumophila. Mol. Microbiol., 1999; 31: 959-970

[69] Hales L.M., Shuman H.A.: Legionella pneumophila contains a type II general secretion pathway required for growth in amoebae as well as for secretion of the Msp protease. Infect. Immun. 1999; 67: 3662-3666

[70] Rossier O., Cianciotto N.P.: Type II protein secretion is a subset of the PilD-dependent processes that facilitate intracellular infection by Legionella pneumophila. Infect. Immun., 2001; 69: 2092 2098

[71] Rossier O., Starkenburg S.R., Cianciotto N.P.: Legionella pneumophila type II protein secretion promotes virulence in the $A / J$ mouse model of Legionnaires' disease pneumonia. Infect. Immun., 2004; 72: 310-321

[72] Cazalet C., Rusniok C., Bruggemann H., Zidane N., Magnier A., Ma L., Tichit M., Jarraud S., Bouchier C., Vandenesch F. i wsp.: Evidence in the Legionella pneumophila genome for exploitation of host cell functions and high genome plasticity. Nat. Genet. 2004; 36: 1165-1173

[73] Chien M., Morozova I., Shi S., Sheng H., Chen J., Gomez S.M., Asamani G., Hill K., Nuara J., Feder M. i wsp.: The genomic sequence of the accidental pathogen Legionella pneumophila. Science, 2004; 305: 1966-1968 
[74] Glöckner G., Albert-Weissenberger C., Weinmann E., Jacobi S., Schunder E., Steinert M., Hacker J., Heuner K.: Identification and characterization of a new conjugation/type IVA secretion system (trb/tra) of Legionella pneumophila Corby localized on two mobile genomic islands. Int. J. Med. Microbiol., 2008; 298: 411-428

[75] DebRoy S., Dao J., Söderberg M., Rossier O., Cianciotto N.P.: Legionella pneumophila type II secretome reveals unique exoproteins and a chitinase that promotes bacterial persistence in the lung. Proc. Natl. Acad. Sci. USA, 2006; 103: 19146-19151

[76] White R.C., Gunderson F.F., Tyson J.Y., Richardson K.H., Portlock T.J., Garnett J.A., Cianciotto N.P.: Type II secretiondependent aminopeptidase LapA and acyltransferase PlaC are redundant for nutrient acquisition during Legionella pneumophila intracellular infection of amoebas. mBio, 2018; 9: e00528-18

[77] Pearce M.M., Cianciotto N.P.: Legionella pneumophila secretes an endoglucanase that belongs to the family- 5 of glycosyl hydrolases and is dependent upon type II secretion. FEMS Microbiol. Lett., 2009; 300: 256-264

[78] Herrmann V., Eidner A., Rydzewski K., Blädel I., Jules M., Buchrieser C., Eisenreich W., Heuneret K.: GamA is a eukaryoticlike glucoamylase responsible for glycogen- and starch-degrading activity of Legionella pneumophila. Int. J. Med. Microbiol., 2011; 301: 133-139

[79] Rossier O., Dao J., Cianciotto N.P.: The type II secretion system of Legionella pneumophila elaborates two aminopeptidases as well as a metalloprotease that contributes to differential infection among protozoan hosts. Appl. Environ. Microbiol., 2008; 74: 753-761

[80] Abdel-Nour M., Duncan C., Prashar A., Rao C., Ginevra C., Jarraud S., Low D.E., Ensminger A.W., Terebiznik M.R., Guyard C.: The Legionella pneumophila collagen-like protein mediates sedimentation, autoaggregation, and pathogen-phagocyte interactions. Appl. Environ. Microbiol., 2014; 80: 1441-1454

[81] Aragon V., Rossier O., Cianciotto N.P.: Legionella pneumophila genes that encode lipase and phospholipase $\mathrm{C}$ activities. Microbiology, 2002; 148: 2223-2231

[82] Söderberg M.A., Cianciotto N.P.: A Legionella pneumophila peptidyl-prolyl cis-trans isomerase present in culture supernatants is necessary for optimal growth at low temperatures. Appl. Environ. Microbiol., 2008; 74: 1634-1638

[83] Aragon V., Kurtz S., Cianciotto N.P.: Legionella pneumophila major acid phosphatase and its role in intracellular infection. Infect. Immun., 2001; 69: 177-185

[84] Tyson J.Y., Vargas P., Cianciotto N.P.: The novel Legionella pneumophila type II secretion substrate NttC contriubtes to infection of amoebae Hartmannella vermiformis and Willaertia magna. Microbiology, 2014; 160: 2732-2744

[85] Flieger A., Gong S., Faigle M., Stevanovic S., Cianciotto N.P., Neumeister B.: Novel lysophospholipase A secreted by Legionella pneumophila. J. Bacteriol., 2001; 183: 2121-2124

[86] Flieger A., Neumeister B., Cianciotto N.P.: Characterization of the gene encoding the major secreted lysophospholipase A of Le- gionella pneumophila and its role in detoxification of lysophosphatidylcholine. Infect. Immun., 2002; 70: 6094-6106

[87] Banerji S., Bewersdorff M., Hermes B., Cianciotto N.P., Flieger A.: Characterization of the major secreted zinc metalloproteasedependent glycerophospholipid:cholesterol acyltransferase, $\mathrm{PlaC}$, of Legionella pneumophila. Infect. Immun., 2005; 73: 2899-2909

[88] McCoy-Simandle K., Stewart C.R., Dao J., DebRoy S., Rossier O., Bryce P.J., Cianciotto N.P.: Legionella pneumophila type II secretion dampens the cytokine response of infected macrophages and epithelia. Infect. Immun., 2011; 79: 1984-1997

[89] Rossier O., Dao J., Cianciotto N.P.: A type II secreted RNase of Legionella pneumophila facilitates optimal intracellular infection of Hartmannella vermiformis. Microbiology, 2009; 155: 882-890

[90] Hiller M., Lang C., Michel W., Flieger A.: Secreted phospholipases of the lung pathogen Legionella pneumophila. Int. J. Med. Microbiol., 2018; 308: 168-175

[91] Flieger A., Frischknecht F., Häcker G., Hornef M.W., Pradel G.: Pathways of host cell exit by intracellular pathogens. Microb. Cell, 2018; 5: 525-544

[92] Hoffmann C., Harrison C.F., Hilbi H.: The natural alternative: Protozoa as cellular models for Legionella infection. Cell. Microbiol., 2014; 16: 15-26

[93] Lang C., Rastew E., Hermes B., Siegbrecht E., Ahrends R., Banerji S., Flieger A.: Zinc metalloproteinase ProA directly activates Legionella pneumophila PlaC glycerophospholipid:cholesterol acyltransferase. J. Biol. Chem., 2012; 287: 23464-23478

[94] Banerji S., Aurass P., Flieger A.: The manifold phospholipases A of Legionella pneumophila - identification, export, regulation, and their link to bacterial virulence. Int. J. Med. Microbiol., 2008; 298: 169-181

[95] Best A., Jones S., Abu Kwaik Y.: Mammalian solute carrier (SLC)like transporters of Legionella pneumophila. Sci. Rep., 2018; 8: 8352

[96] Price C.T., Richards A.M., Von Dwingelo J.E., Samara H.A, Abu Kwaik Y.: Amoeba host-Legionella synchronization of amino acid auxotrophy and its role in bacterial adaptation and pathogenic evolution. Environ. Microbiol., 2014; 16: 350-358

[97] Rehman S., Grigoryeva L.S., Richardson K.H., Corsini P., White R.C., Shaw R., Portlock T.J., Dorgan B., Zanjani Z.S., Fornili A., Cianciotto N.P., Garnett J.A.: Structure and functional analysis of the Legionella pneumophila chitinase ChiA reveals a novel mechanism of metal-dependent mucin degradation. PLoS Pathog., 2020; 16: e1008342

[98] Portlock T.J., Tyson J.Y., Dantu S.C., Rehman S., White R.C., McIntire I.E., Sewell L., Richardson K., Shaw R., Pandini A., Cianciotto N.P., Garnett J.A.: Structure, dynamics and cellular insight into novel substrates of the Legionella pneumophila type II secretion system. Front. Mol. Biosci., 2020; 7: 112

[99] de Felipe K.S., Glover R.T., Charpentier X., Anderson O.R., Reyes R., Pericone C.D, Shuman H.A.: Legionella eukaryotic-like type IV substrates interfere with organelle trafficking. PLoS Pathog., 2008; 4: e1000117 
[100] de Felipe K.S., Pampou S., Jovanovic O.S., Pericone C.D., Ye S.F., Kalachikov S., Shuman H.A.: Evidence for acquisition of Legionella type IV secretion substrates via interdomain horizontal gene transfer. J. Bacteriol., 2005; 187: 7716-7726

[101] Gomez-Valero L., Rusniok C., Cazalet C., Buchrieser C.: Comparative and functional genomics of Legionella identified eukaryotic like proteins as key players in host-pathogen interactions. Front. Microbiol., 2011; 2: 208

[102] Lurie-Weinberger M.N., Gomez-Valero L., Merault N., Glöckner G., Buchrieser C., Gophna U.: The origins of eukaryotic-like proteins in Legionella pneumophila. Int. J. Med. Microbiol., 2010; 300: 470-481

[103] Schroeder G.N., Petty N.K., Mousnier A., Harding C.R., Vogrin A.J., Wee B., Fry N.K., Harrison T.G., Newton H.J., Thomson N.R. i wsp.: Legionella pneumophila strain $130 \mathrm{~b}$ possesses a unique combination of type IV secretion systems and novel Dot/lcm secretion system effector proteins. J. Bacteriol., 2010; 192: 6001-6016

[104] Hughes E.D., Swanson M.S.: How Legionella defend their turf. eLife, 2019; 8: e48695

[105] Duncan C., Prashar A., So J., Tang P., Low D.E., Terebiznik M., Guyard C.: Lcl of Legionella pneumophila is an immunogenic GAG binding adhesion that promotes interactions with lung epithelial cells and plays a crucial role in biofilm formation. Infect. Immun., 2011; 79: 2168-2181

[106] Lucas C.E., Brown E., Fields B.S.: Type IV pili and type II secretion play a limited role in Legionella pneumophila biofilm colonization and retention. Microbiology, 2006; 152: 3569-3573

[107] Stewart C.R., Rossier O., Cianciotto N.P.: Surface translocation by Legionella pneumophila: A form of sliding motility that is dependent upon type II protein secretion. J. Bacteriol., 2009; 191: 1537-1546

[108] Söderberg M.A., Rossier O., Cianciotto N.P.: The Type II protein secretion system of Legionella pneumophila promotes growth at low temperatures. J Bacteriol., 2004; 186: 3712-3720
[109] Söderberg M.A., Dao J., Starkenburg S. R., Cianciotto N. P.: Importance of type II secretion for survival of Legionella pneumophila in tap water and in amoebae at low temperatures. Appl. Environ. Microbiol., 2008; 74: 5583-5588

[110] Tyson J.Y., Pearce M.M., Vargas P., Bagchi S., Mulhern B.J., Cianciotto N.P.: Multiple Legionella pneumophila type II secretion substrates, including a novel protein, contribute to differential infection of amoebae Acanthamoeba castellanii, Hartmannella vermiformis, and Naegleria lovaniensis. Infect. Immun., 2013; 81: 1399-1410

[111] Polesky A.H., Ross J.T., Falkow S., Tompkins L.S.: Identification of Legionella pneumophila genes important for infection of amoebas by signature-tagged mutagenesis. Infect. Immun., 2001; 69: 977-987

[112] White R.C., Cianciotto N.P.: Type II secretion is necessary for optimal association of the Legionella-containing vacuole with macrophage Rab1B but enhances intracellular replication mainly by Rab1B-independent mechanisms. Infect. Immun., 2016; 84: 33133327

[113] Mallama C.A., McCoy-Simandle K., Cianciotto N.P.: The type II secretion system of Legionella pneumophila dampens the MyD88 and Toll-like receptor 2 signaling pathway in infected human macrophages. Infect. Immun., 2017; 85: e00897-16

[114] Grabiec A., Meng G., Fichte S., Bessler W., Wagner H., Kirschning C.J.: Human but not murine Toll-like receptor 2 discriminates between tri-palmitoylated and tri-lauroylated peptides. J. Biol. Chem., 2004; 279: 48004-48012

[115] Lang C., Hiller M., Flieger A.: Disulfide loop cleavage of Legionella pneumophila PlaA boosts lysophospholipase A activity. Sci. Rep., 2017; 7: 16313

[116] Jan A.T.: Outer membrane vesicles (OMVs) of gram-negative bacteria: A perspective update. Front. Microbiol., 2017; 8: 1053 